\title{
Küresel İnovasyon Endeksi Verilerinin Kümeleme Analizi ile Değerlendirilmesi
}

\author{
Filiz GÜRTUNA, Ulviye POLAT ${ }^{* 1}$ \\ ${ }^{1}$ Tekirda ̆̆ Namık Kemal Üniversitesi, Çorlu Mühendislik Fakültesi, Endüstri Mühendisliği \\ Bölümü, Tekirdağ
}

Geliş tarihi: 06.11 .2019

Kabul tarihi: 30.07 .2020

$\ddot{O} z$

Hızla değişen teknoloji ve küreselleşme ile rekabetin giderek artması inovasyon çalışmalarının şirketler ve ülkeler açısından önemini arttırmaktadır. İşletmelerin ve/veya ülkelerin rekabet güçlerini belirleyebilmeleri, mevcut durum analizi yapabilmeleri ve yol haritası oluşturabilmeleri için inovasyonun ölçülebilmesi önem arz etmektedir. İnovasyona etki eden pek çok faktör olduğu gibi inovasyonun ölçülmesi ile ilgili de değişik çalışmalar mevcuttur. Yılda bir yayınlanan Küresel İnovasyon Endeksi (KIE), inovasyonu etkileyen birçok göstergeyi kullanarak ülkelerin inovasyon seyirlerini ölçmektedir. Bu çalışmada, $2018 \mathrm{KIEE} \mathrm{Raporunda} \mathrm{yer} \mathrm{alan} \mathrm{inovasyon} \mathrm{girdi} \mathrm{ve} \mathrm{çıktı} \mathrm{alt} \mathrm{endeksi} \mathrm{ana} \mathrm{göstergelerinin} \mathrm{her}$ birine ait 3 alt başlıktaki göstergeler dikkate alınmış ve toplam 21 değişken kullanılarak, 126 ülkeye ait veriler kümeleme analizi ile incelenmiştir. Kümeleme analizi yöntemlerinden Ward's Tekniği ve KOrtalamalar Yöntemi kullanılmıştır.

Anahtar Kelimeler: İnovasyon, Küresel inovasyon endeksi, Kümeleme analizi

\section{Evaluation of Global Innovation Index with Clustering Analysis}

\begin{abstract}
Rapidly changing technology and the rapid increase in competition with globalization increases the importance of innovation efforts for companies and countries. It is important to measure innovation in order for companies and/or countries to determine their competitiveness, to analyze the current situation and to determine a road map for innovation. As there are many factors affecting innovation, there are various studies on measuring innovation. Annually published the Global Innovation Index (GII) measures the innovation of countries using many indicators that affect innovation. In this study, the three subheadings under each of the main indicators of innovation input and output subscale in the 2018 GII report were taken into consideration and the data of 126 countries were analyzed by clustering analysis. In this study, Ward's Technique and K-Means method are used.
\end{abstract}

Keywords: Innovation, Global innovation index, Clustering analysis

*Sorumlu yazar (Corresponding author): Ulviye POLAT, upolat@nku.edu.tr 


\section{GíRiș}

Günümüzde işletmeler teknolojinin hizla değişmesi ve küreselleşme ile artan rekabet sayesinde yenilikçi olmaya zorlanmaktadır. İnovasyon çalışmaları bu anlamda işletmeler için proaktif bir yaklaşım sağlamaktadır. İnovasyon çalışmaları 3 şekilde gruplandırılabilir: Birinci grup, üniversite ve Araştırma Geliştirme (ArGe) merkezlerinden oluşan bilimsel grup, ikincisi bioteknoloji alanı gibi yüksek teknoloji içeren inovasyon grubu ve üçüncüsü ise medya, sanat ve tasarım tabanlı yaratıcı inovasyon çalışmalarının bulunduğu gruptur [1]. Bir işletme içindeki inovasyon sürecinin yapısının, küresel rekabete ve küresel ekonomilere bağlı olarak inovasyona verilen önemle ilgili olduğu söylenebilir [2]. Bu nedenle özellikle uluslararası firmalarda inovasyon süreci ve bilgi transferi önemli bir rol oynamaktadır. Lee ve arkadaşları [3], teknolojinin ve rekabetçiliğin hızla değiştiği iş ortamında işletmelerin hayatta kalması için inovasyonun kritik bir faktör haline geldiğini belirtmişlerdir.

Xie ve arkadaşları [4] işletmelerin finansal performans sonuçlarına etki edebilecek yeşil teknoloji kullanımının inovasyonun uygulama sürecine etkisi ile ilgili öneriler sunmuşlardır. Çalışmalarında yeşil teknoloji, yeşil proses inovasyonu ve yeşil ürün inovasyonu olarak iki grupta değerlendirilmiş olup, yeşil proses ve yeşil ürün inovasyonlarının ilişkili olduğu belirtilmiştir. Yeșil proses inovasyonu kaynak kullanımının azaltılması, enerji verimliliğinin arttırılması, geri dönüştürülebilir malzeme ve teknoloji kullanımı, kirlilik kontrolü sağlayan ekipmanların kullanımı, kirlilik kontrolünü sağlayan projelerin uygulanması konularını; yeşil ürün inovasyonu ise zararlı maddelerin içerik olarak bulunmaması, enerji tüketimlerinin azalacak şekilde ürün modifikasyonlarının geliștirilmesi, çevre dostu paketleme sistemlerinin kullanımı konularını içermektedir.

İnovasyon özellikle küçük ölçekteki işletmelerin hayatta kalabilmesi için hayati bir öneme sahiptir [5]. Baregheh ve arkadaşları [6] küçük ölçekli işletmelerin inovasyon kazançları ile ilgili olarak; üstün kalitede ürün üretimi, çeşitlendirilmiş ürün sinıfları, üretken süreçlerin modernize edilebilmesi, üretilebilirliğin yükseltilmesi, maliyetlerin azaltılması ve yeni pazarlara girme kolaylığı avantajları olduğundan bahsetmişlerdir.

İşletmelerde uygulanan inovasyon süreçlerinin etkinliğinin belirlenmesine yönelik çeşitli bilimsel çalışmalar mevcuttur. Örneğin, firmaların inovasyon çalışmalarının seviyesinin belirlenmesi için insan kaynakları durumu, ArGe için yapılan finansal yatırım, yatırım tipi, organizasyonun oluşumu, ArGe ile ilgili fiziksel altyapı, inovasyona bağl1 organizasyon kültürü, inovasyon süreçlerinin gelişmişliği, teknoloji ve inovasyon yönetim uygulamaları, inovasyon göstergeleri olarak kullanılabilir [2]. Saraceni ve arkadaşları [2], inovasyon sonuçları ile ilgili göstergeleri inovasyon projelerinin sayısı, yeni ürün veya hizmetlerden elde edilen gelir yüzdesi, yeni ve hizmetlerle ilgili maliyetler, teknolojinin başkalarına satılması, patent sayısı ve inovasyon ödüllerinin sayısı olarak belirlemişlerdir. Çalışmalarında, Brezilya'da uluslararası firmalarda belirlenen göstergeler ile inovasyon endeksleri sanayi sınıfları temelinde değerlendirilmiştir. Çalışma, firmaların üst düzey yöneticilerine anket uygulanarak gerçekleştirilmiştir. Çalışmada sanayi sinıfları ile inovasyon endeksi arasında bağlantı olduğu ortaya çıkarılmıştır. Bir başka çalışmada da Türkiye'de beş teknoparkta bulunan 254 işletmenin inovasyon uygulamaları ile ilgili bir anket gerçekleştirilmiş ve sonuçlar istatistiksel olarak analiz edilmiştir. İnovasyon çalışmaları ile ilgili olarak nitelikli personel istihdamı, rakipleri gözlemleme, stratejik işbirlikleri, bilgi paylaşımı, inovasyon algısı ana kategorileri incelenmiştir [7]. Franco ve Oliveira [8] Brezilya, Rusya, Hindistan, Çin ve Güney Afrika ülkelerinin (BRICS) 20082013 arasındaki Küresel İnovasyon Endeksi (KIE) girdi ve çıtı verilerini regresyon analizi ile incelemişlerdir. Çalışmada girdi verileri kuruluşlar, insan sermayesi, altyapı, pazar karmaşıklığı, iş karmaşıklığı gibi başlıklarda toplanmış olup bu başlıklar çok sayıda alt girdilerden oluşturulmuştur. Çıktı verileri de benzer şekilde 
bilgi ve teknoloji çıktıları ve yaratıcı çıktılar alt başlıkları altında toplanmış olup çok sayıda alt çıktıyı içermektedir. Dziallas ve Blind [9], inovasyon süreçlerinin yürütülmesinde önemli rol alan inovasyon göstergelerine dair 1980-2015 yılları arasında yapılan çalışmaları kapsamlı şekilde incelemiştir.

İnovasyonla ilgili yapılan araştırmalardan önemli biri de Cornell Üniversitesi, INSEAD (Avrupa İşletme Yönetimi Enstitüsü) ve WIPO (Dünya Fikri Mülkiyetler Örgütü) tarafından yılda bir yayınlanan KİE'dir. Bu endeks inovasyonu etkileyen birçok değişkeni kullanarak ülkelerin inovasyon seviyesini ölçmekte ve ülkeleri göstergelere göre siralamaktadır. Bu endeks ile kurumlar, insan sermayesi ve araştırma, altyap1, piyasalar vb. birçok değişken sayısal olarak ifade edilmektedir. KİE hesaplanmasında her yıl değişkenler farklılık gösterebilmekte, yeni değişkenler eklenip çıkarılabilmektedir. Hızlı bir şekilde gelişen teknoloji, endekse yeni değişkenlerin entegrasyonunu sağlamaktadır. Silva ve arkadaşları [10] Latin Amerika ve Karayip ülkelerinin WIPO tarafından sağlanan KİE verilerini, çok kriterli karar verme yöntemlerinden TOPSIS'i kullanarak incelemişlerdir. TOPSIS yönteminde değerlendirme kriterleri olarak kuruluşlar, insan sermayesi, araştırma, altyapı, piyasa karmaşıklığ 1 iş karmaşıklığ bilgi\&teknoloji çıktıları, yaratıcı çıktılar kullanılmıştır [10].

Ülkeler arasında inovasyon endeksleri kullanılarak sıralama oluşturulabilmektedir. Fakat ülkeler inovasyon göstergeleri bakımından birbiri ile benzerlik ya da farklılık gösterebilirler ve bu durum endekslere yansımayabilir. $\mathrm{Bu}$ çalışma, ülkelerin inovasyon performansı kapsamında birbirlerine olan benzerlik ve farklılıklarını ve KİE endeks değerlerinin benzerlikler ve farklılıkları ne kadar yansıtabildiğini inceleyebilmek, benzerlik ve farklılıkların hangi değişkenlerden kaynaklanabileceğini ortaya koymak, verileri benzerlik ve farklılıklarına göre gruplayabilmek için kümeleme analizi tekniklerinin kullanımını açıklayarak literatüre katkı sağlamayı amaçlamaktadır. İlave olarak, bu tür bir analizinin sonuçlarının geliştirilmiş bir inovasyon ölçüm endeksinin sonuçlarıyla karşılaştırılması ve endeksin tutarlılığının ölçülmesinde kullanılması da başka çalışmalar için mümkün olacaktır.

Kümeleme analizi farklı disiplinlerde uygulanabilen (biyoinformatik, pazarlama gibi), benzer öğeleri gruplandırarak filtreleme özelliği kazandıran bir veri analizi aracıdır. Özellikle gerçekçi hedeflerle kümeleme analizi yapılması sonuçları yanıltıcılıktan uzaklaştıracaktır. Kümeleme analizi veriyi ön işleme, kümelenebilirlik değerlendirmesi, algoritma seçimi ve uygulanması ve kalite değerlendirmesi olarak dört aşamadan oluşmaktadır [11]. Çakmak ve arkadaşları [12] aşamalı ve aşamalı olmayan kümeleme tekniklerini açıklamış, Devlet İstatistik Enstitüsü 1990 ve 2000 yıllarına ait kültür istatistiklerini çalışmalarında kullanmışlardır. Araştırma kapsamına alınan iller kültürel yapılarına göre her iki dönem için ayrı ayrı kümelenerek son 10 yıl içerisinde illerin kültürel yapılarında meydana gelen değişimleri incelenmiştir. Bir başka çalışmada, klasik ve bulanık kümeleme yöntemleri ile, Denizli ili için 2004, 2005 ve 2006 yıllarına ait trafik kaza verileri kümelere ayrılmış ve ortaya çıkan sonuçlar yorumlanarak, belirlenen hususlar için çeşitli çözüm önerileri getirilmiştir [13]. Atalay ve Tortum [14], 1997-2006 yılları arasında Türkiye'deki illerde meydana gelen şehir diş1 trafik kaza verilerini kullanarak her il için ölüm ve yaralanma oranlarını hesaplamış ve çıkan oranlara göre K-Ortalamalar ve bulanık C-Ortalamalar yöntemlerini kullanarak kümeleme analizi yapmıştır. Çalışmada, iki yönteme göre yapılan kümeleme analizi ile iller beş kümeye ayrılmış ve elde edilen sonuçlar karşılaştırılarak bulanık COrtalamalar tekniğinin K-Ortalamalar tekniği kadar doğru ve tutarlı sonuçlar verdiği gözlemlenmiştir. Bir başka çalışmada, Türkiye'nin, Avrupa Birliği üyesi ülkeleri karşısında sürdürülebilir kalkınma düzeyi incelenerek ve bu kavramın Avrupa Birliği için önemini vurgulamak adına sürdürülebilir kalkınma değişkenleri kullanılarak, kümeleme analizi yardımıyla ülke kümeleri belirlenmiş ve Türkiye'nin hangi ülkelerle aynı kümelerde yer aldığı saptanmıştır [15]. 
İnovasyon çalışmalarında kümeleme analizinin kullanıldığı bilimsel araştırmalar literatürde mevcuttur. Örneğin, Rai ve arkadaşları [16] elektronik tedariği inovasyonlarının etkinliğinin değerlendirmesinde 166 firmanın verilerini kullanarak kümeleme analizi gerçekleştirmiştir. Bir başka çalışmada Türkiye'nin inovasyon açısından kalkınmış ülkeler arasındaki yerinin analizi ve tespiti adına 2010 y1lı Avrupa İnovasyon Karnesi'nin 25 göstergesi arasından Türkiye'nin ve 29 ülkenin verilerinin olduğu 13 inovasyon göstergesi kullanılarak, kümeleme analizi uygulanmış ve ülkeler 4 kümeye ayrılmıştır [17]. Sonuçların doğruluğunu test etmek üzere Ayırma Analizi (Discriminant Analysis) uygulanmış ve geçerli bir ayrım olduğunu belirten değerler elde edilmiştir. Türkiye'nin bu göstergelere göre Avrupa Birliği (AB) ülkeleri arasında nerede bulunduğu, AB'yi yakalayıp, sürdürülebilir ve hızlı bir kalkınma yakalayabilmesi için inovasyona önem vermesi ve gerekli harcamaları artırması gerektiği ve bunun için ise en kritik inovasyon göstergesinin ArGe harcamaları olduğu ortaya konulmuştur. Şimşit ve arkadaşları [18] inovasyonun bilgi ve iletişim teknolojileri (BIT) çerçevesinden değerlendirmesini yapmışlardır. KİE raporunda yer alan BİT göstergeleri ve destekleyici nitelikte olan diğer göstergeler belirlenerek, bunlar üzerinde Temel Bileşenler Analizi (Principal Component Analysis) tekniği kullanılmıştır. Elde edilen sonuçlar doğrultusunda raporda yer alan 142 ülke kümelenmiştir. Yapılan bu çalışma, ülkelere kendi performanslarını değerlendirmeleri, küresel anlamda konumlarını görebilmeleri ve inovasyon stratejilerini belirlemeleri açısından katkı sağlamıştır [18]. Ekonomik İşbirliği ve Kalkınma Örgütü üyesi 34 ülkenin sosyoekonomik yapılarını gösteren makroekonomik ve sosyo-kültürel göstergeler gibi 30 değişkene ait veriler kullanılarak bulanık kümeleme ve K-Medoid kümeleme yöntemleri ile bu ülkeler gelişmiş ve daha az gelişmiş olmak üzere iki ayrı kümeye ayrılmıştır. Bu ülkelerin gelişmişlik bakımından hangi ülkelerle benzeştiği veya hangileriyle farklılaşma gösterdiği ortaya konulmuştur [19]. Beklenmedik Durum Teorisi (Contingency Theory) ile ilgili Portekiz'de 500 firmada anket yolu ile yapılan bir araştırmada, araştırma sonuçları için Boolean Değişken kümeleme tekniği kullanılmıştır [20]. Araştırmada rekabetçilik, çevre, belirsizlik ve inovasyon faktörleri hedef maliyetlendirme kapsamında değerlendirilmiştir. Kore'de küçük ve orta ölçekli firmalarda araştırma ve geliştirme çalışmalarında inovasyon etkinliğini ölçmek için işbirliği sınıflarının ve iş birliği stratejilerinin incelemesinde Veri Zarflama Analizi ve kümeleme analizi teknikleri kullanılmıştır [3]. Proksch ve arkadaşları [21] ulusal sağlı sistemlerinin inovasyon seviyelerinin belirlenmesi için Ward's tekniğini kullanarak kümeleme analizi gerçekleştirmiştir. Çalışmada 30 OECD ülkesinin inovasyon çıktısı kullanılmış olup, İskandinav ülkeleri, Hollanda ve İsviçre bilgi üretimi ve bilginin ticarileştirilmesinde en yüksek inovasyon çıktısına sahip ülkeler olarak elde edilmiştir. Bir başka çalışmada 34 OECD ülkesinin 2012 yılına ait Dünya Bankası'nın eğitim, bilgi, ekonomik teşvik ve kurumsal rejim, inovasyon, bilgi ve iletişim teknolojileri endeks verileri kullanılarak hiyerarşik kümeleme analizi ile gruplandırma yapılmıştır [22]. Irac ve Lopez [23] Avrupa ülkelerini güney ülkeler grubu ve diğer ülkeler grubu olarak iki kümeye ayırmış; her kümeyi iş hareketliliği, bilgi, regülasyonlar ve kuruluşların kalitesi olmak üzere 4 ana gösterge ve 27 alt gösterge kullanarak incelemiştir.

\section{MATERYAL VE METOT}

\subsection{Materyal}

$\mathrm{Bu}$ çalışmada kullanılan inovasyon göstergeleri, KİE Raporu inovasyon girdi ve çıktı alt endekslerine ait değişkenlerdir [24]. Bu değişkenler ve onlara karşılık gelen istatistiksel veriler sırasıyla Çizelge 1 ve Çizelge 2'de verilmiştir. Çizelge 22018 KİE verileri kullanılarak hazırlanmıştır. 
Çizelge 1. Kümeleme analizinde kullanılan değişkenler

\begin{tabular}{|l|l|l|}
\hline X1: Politik Çevre & X8: Genel Altyapı & X15: Bilgi İçselleştirmesi \\
\hline X2: Yasal Çevre & X9: Ekolojik Sürdürülebilirlik & X16: Bilgi Üretimi \\
\hline X3: İşletme Çevresi & X10: Kredi & X17: Bilginin Etkisi \\
\hline X4: Eğitim & X11: Yatırım & X18: Bilginin Yayılımı \\
\hline X5: Yükseköğretim & X12: Ticaret ve Rekabet & X19: Maddi Olmayan Varlıklar \\
\hline X6: ArGe & X13: Bilgi Çalışanları & X20: Yaratıcı Ürün ve Hizmetler \\
\hline $\begin{array}{l}\text { X7: Bilgi ve İletiş̧im } \\
\text { Teknolojileri }\end{array}$ & X14: İnovasyon Bağlantılları & X21: Online Yaratıcıılı \\
\hline
\end{tabular}

Çizelge 2. 2018 KİE değişkenlerinin istatistiksel değerleri

\begin{tabular}{|c|c|c|c|c|c|c|c|}
\hline Değişken & $\begin{array}{c}\text { Ülkeler } \\
\text { genelinde } \\
\text { ortalama } \\
\text { değer }\end{array}$ & $\begin{array}{c}\text { Ülkeler } \\
\text { genelinde } \\
\text { en düşük } \\
\text { değer }\end{array}$ & $\begin{array}{c}\text { Ülkeler } \\
\text { genelinde en } \\
\text { yüksek } \\
\text { değer }\end{array}$ & Değişken & $\begin{array}{c}\text { Ülkeler } \\
\text { genelinde } \\
\text { ortalama } \\
\text { değer }\end{array}$ & $\begin{array}{c}\text { Ülkeler } \\
\text { genelinde } \\
\text { en düşük } \\
\text { değer }\end{array}$ & $\begin{array}{c}\text { Ülkeler } \\
\text { genelinde } \\
\text { en yüksek } \\
\text { değer }\end{array}$ \\
\hline X1 & 55,78 & 0 & 100 & $\mathrm{X} 12$ & 60,69 & 16,9 & 92,3 \\
\hline X2 & 66,32 & 15,6 & 98,6 & $\mathrm{X} 13$ & 38,14 & 0 & 85,6 \\
\hline $\mathrm{X} 3$ & 70,11 & 40 & 93 & $\mathrm{X} 14$ & 31,45 & 3 & 77,9 \\
\hline $\mathrm{X} 4$ & 46,52 & 0 & 90,5 & $\mathrm{X} 15$ & 31,92 & 12 & 77,9 \\
\hline $\mathrm{X} 5$ & 31,60 & 0 & 96,6 & $\mathrm{X} 16$ & 19,84 & 0,9 & 88,9 \\
\hline $\mathrm{X} 6$ & 20,4 & 0 & 88,6 & $\mathrm{X} 17$ & 35,03 & 0,4 & 67 \\
\hline $\mathrm{X} 7$ & 56,92 & 9,4 & 93,8 & $\mathrm{X} 18$ & 24,89 & 25 & 86 \\
\hline $\mathrm{X} 8$ & 39,35 & 1,6 & 73,4 & $\mathrm{X} 19$ & 41,85 & 0,1 & 71,9 \\
\hline $\mathrm{X} 9$ & 39,53 & 18,3 & 81,6 & $\mathrm{X} 20$ & 24,39 & 0 & 61,3 \\
\hline $\mathrm{X} 10$ & 39,52 & 0,3 & 89,6 & $\mathrm{X} 21$ & 15,58 & 0 & 67,1 \\
\hline $\mathrm{X} 11$ & 43,95 & 23,5 & 77,1 & & & & \\
\hline
\end{tabular}

21 alt endeksin her biri şu göstergelere dayandırılır: X1 (Politik Çevre): Siyasi istikrar ve güvenlik, hükümet etkinliği, X2 (Yasal Çevre): Yasal düzenlemelerin kalitesi, yasalar, işten çıarma maliyetleri, X3 (İşletme Çevresi): İş yeri açma kolaylığı, iflas durumundan kurtulma kolaylığı, X4 (Eğitim): Eğitim harcamaları (\%GSYIH), devlet fonu/öğrenci, okulda geçen süre/yll, fen Bilimlerinde PISA notu, ortaöğretimde öğrenci başına öğretmen ortalaması, X5 (Yükseköğretim): Yükseköğretime kayıt (\%), Fen Bilimleri ve Mühendislik bölümlerinden mezun olma (\%), öğrenci hareketliliği, X6 (Araştırma ve Geliştirme): Araştırmacılar, araştırma-geliştirmede brüt harcamalar (\%GSYH), Küresel ArGe firmaları, QS üniversite notu, X7 (Bilgi ve İletişim Teknolojileri): BİT'e erişim, BİT kullanımı, devletin online hizmetleri, e-katılım, X8 (Genel Altyapı): Elektrik üretimi, lojistik performans1, brüt sermaye performansı, X9 (Ekolojik Sürdürülebilirlik): $\quad$ GSYH/enerji kullanımı, çevresel performans, ISO 14001 çevre sertifikası, X10 (Kredi): Kredi alma kolaylığı, özel sektörün kullandığı yerli krediler, mikrofinans brüt krediler, X11 (Yatırım): Küçük yatırımcıların korunması, piyasa kapitalizasyonu, girişim sermayesi anlaşmaları, X12 (Ticaret ve Rekabet): Uygulanan tarife oranları, yerel rekabetin yoğunluğu, iç piyasa ölçeği, X13 (Bilgi Çalışanları): Bilgi sektörü çalışan yoğunluğu, formal eğitim veren firmalar, ArGe çalışmaların GSYH'deki payı, ArGe çalışmalarını finanse eden firmalar, kadın istihdamı, X14 (İnovasyon Bağlantıları): Üniversite-Sanayi işbirliği, küme gelişimi, yurtdışı destekli ArGe çalışmaları \% GSYH, stratejik işbirliği anlaşmaları, patent aileleri, X15 (Bilgi İçselleştirmesi): Fikri mülkiyet ödemeleri, yüksek teknolojili ürün ihracatı, BIT hizmetleri ihracatı, girişimcilerin işletme kabiliyeti, doğrudan yabancı yatırım girişleri, X16 (Bilgi Üretimi): Patent başvuruları, PİA (Patent İşbirliği Anlaşması) patent başvuruları, faydalı 
model başvuruları, bilimsel ve teknik makaleler, atıf yapılabilir çalışmalar, X17 (Bilginin Etkisi): ÖSO (Özel Sektör Ortaklıkları) çalışanın büyüme oranı, yeni işletmeler, bilgisayar yazılımı harcamaları, ISO 9001 kalite sertifikaları, orta ve yüksek teknolojili üretim, X18 (Bilginin Yayılımı): Fikri mülkiyet makbuzları, yüksek teknoloji ürün ihracat1, BİT hizmet ihracat1, doğrudan yabancı yatırımlar, X19 (Maddi Olmayan Varlıklar): Ticari markalar, ezndüstriyel tasarım uygulamaları, BIT ve iş modeli tasarımı, BIT ve örgütsel model tasarımı, X20 (Yaratıcı Ürün ve Hizmetler): Kültürel hizmetler ihracatı, ulusal filmler, küresel medya ve eğlence pazarı, basım ve yayın, yaratıcı ürün ihracatı, X21 (Online Yaratıcılı): Toplam domain sayısı, ülke kodu, Wikipedia editi, mobil uygulama oluşturma.

Bu 21 değişken kendi içlerinde gruplara ayrılmakta ve ortalamalar alınarak aşağıdaki göstergelere ait değerler elde edilmektedir.

- Kurumlar: Politik Çevre, Yasal Çevre, İşletme Çevresi

- İnsan Sermayesi ve Araştırma: Eğitim, Yükseköğretim, Araştırma ve Geliştirme

- Altyapı: Bilgi ve İletişim Teknolojileri, Genel Altyap1, Ekolojik Sürdürülebilirlik

- Piyasaların Gelişmişliği: Kredi, Yatırım, Ticaret ve Rekabet

- İş Dünyasının Gelişmişliği: Bilgi Çalışanları, İnovasyon Bağlantıları, Bilgi İçselleştirilmesi

- Bilgi ve Teknoloji Çıktıları: Bilgi Üretimi, Bilginin Etkisi, Bilginin Yayılımı

- Yaratıcı Çıktılar: Maddi Olmayan Varlıklar, Yaratıcı Ürün ve Hizmetler, Online Yaratıcılık.

Elde edilen göstergelerden 'Kurumlar, İnsan Sermayesi ve Araştırma, Altyapı, Piyasaların Gelişmişliği ve İş Dünyasının Gelişmişliği' değerlerinin ortalaması ile bulunan İnovasyon Girdi Alt Endeksi ile 'Bilgi ve Teknoloji Çıktıları ve Yaratıcı Çıktılar' değerlerinin ortalaması ile bulunan İnovasyon Çıktı Alt Endeksi'nin ortalaması alınarak 0 ile 100 arasında değer alabilen KİE elde edilir.
Çizelge 1'de belirtilen değerleri elde etmek için toplam 80 alt değişken kullanılmaktadır. Fakat bu alt değişkenler zaman içinde artıp azalabilmektedir. Ayrıca, 80 değişken çok farklı değerler alabilmektedir. Bunlardan yola çıkarak hesaplanan 21 değişken ise 0 ile 100 arasında bir değere sahiptir. $\mathrm{Bu}$ nedenle bu çalışmada 80 değişken yerine onlardan elde edilerek belirlenen 21 değişken veri olarak kullanılmıştır.

Bazı ülkeler için 21 değişkenin hepsine ait veriler mevcut değildir; örneğin Kanada'ya ait yükseköğretim verisinin olmaması gibi. Çalışmada, eksik veriler için 0 değeri kullanılmıştır. Eksik verilerin yerine 0 değerinin kullanılması böyle durumlarda başvurulan yöntemlerden biridir. 0 değerinin dahil olduğu ve hariç bırakıldığı durumlar için ortalama değerlerinin kontrolü yapılarak yanlılık oluşturmadığı ve sonuçların değiştirilmediği öngörülmüştür. Örneğin X20 değişkeni için her iki durumdaki ortalama değerler 22.39 ve 22.57 olarak elde edilmiştir. Bir diğer alternatif ise verilerin tümüyle çıkartılarak analizin tekrarlanmasıdır. $\mathrm{Bu}$ durumda very kaybı sözkonusu olacağı için çalışmada tercih edilmemiştir.

Bu çalışmada kümeleme analizi gerçekleştirilirken PASW Statistics 18 paket programı kullanılmıştır.

\subsection{Metot}

Veri madenciliği yöntemlerinden biri olan kümeleme analizi, verilerin birbirleriyle olan benzerlikleri ya da farklılıkları göz önünde bulundurularak kümelere ayrılması işlemidir ve kümelendirme gerektiren birçok alanda kullanılabilir. Çakmak ve arkadaşları [12]'ına göre, veriler kümelere ayrılırken kullanılabilecek değişik benzerlik ve farklılık fonksiyonları olsa da genellikle benzerlik veya farklılıklar bir uzaklık fonksiyonu üzerinden tanımlanır. En yaygın olarak Öklid, Manhattan ve Minkowski uzaklık fonksiyonları kullanılır. Bu çalışma kapsamında Öklid uzaklık fonksiyonu kullanılmıştır (Eşitlik 1).

$\mathrm{d}_{\mathrm{ij}}=\sqrt{\sum_{k=1}^{n}\left(x_{k}^{i}-x_{k}^{j}\right)^{2}}$ 
Burada $\mathrm{d}_{\mathrm{ij}}, R^{n}$,de yer alan iki nokta $x^{i}$ ve $x^{j}$ arasındaki uzaklığ 1 belirtir.

Kümeleme analizi, bu çalışmada, iki amaçla kullanılmıştır. Birincisi; inovasyon endeksleri baz alınarak ülkelerin 3'lü (Düşük-Orta-Yüksek) ve 5'li (Düşük-Düşük Orta-Orta-Orta YüksekYüksek) gruplara ayrılmasıdır. Sadece endeks değerlerine bakıp böyle bir kümeleme yapmak kolay değildir ve kümeleme analizi bu probleme analitik bir yaklaşım getirir. $\mathrm{Bu}$ çalışmada geliştirilen yaklaşım bir endeksin veya sıralamanın mevcut olduğu herhangi bir başka alanda da kullanılabilir. İkincisi; KİE'yi belirlerken kullanılan 21 göstergeye ait verilerin kullanılmasıyla ülkelerin 3,4 ve 5 gruba ayrılmasıdır. $\mathrm{Bu}$ gruplar sadece kendi içinde benzerlik gösteren ülkelerin gruplanmasını yansıttığı için herhangi bir sıralama şeklinde yorumlanmaz. $\mathrm{Bu}$ sonuçlardan yola çıkılarak endeksin benzerlikler ve farklılıkları ne denli yansıttığı, analiz sonuçları ile gösterdiği tutarlılık hakkında da bir değerlendirme yapılabilir.

Kümeleme analizindeki yöntemler en genel haliyle hiyerarşik ve hiyerarşik olmayan yöntemler şeklinde ayrılır [12]. Hiyerarşik olmayan yöntemlerin aksine, hiyerarşik yöntemlerde bir kümeye aidiyet belirlendikten sonra değiştirilmez. $\mathrm{Bu}$ çalışmada, iki yaklaşımın sonuçlarını da değerlendirebilmek için, her iki yöntemden birer teknik kullanılmıştır. Hiyerarşik yöntemlerden Ward's tekniği ve hiyerarşik olmayan yöntemlerden K-Ortalamalar yöntemi kullanılmıştır. Ward's tekniği ve K-Ortalamalar yöntemi küme içi benzerlikleri maksimum kılmaları ve literatürde de en sık kullanılan yöntemlerden olmaları sebebiyle bu çalışmada tercih edilmiştir.

\subsubsection{Ward's Tekniği}

Ward's tekniği genel olarak kümeler içi varyansı minimum yapmayı amaçlar ve hata kareler toplamına ilişkin aşağıdaki Eşitlik 2'den yararlanılır.

$\sum_{i=1}^{n} x_{i}^{2}-\left(\sum_{i=1}^{n} x_{i}\right)^{2} / \mathrm{n}$
Kümeler, küme ortasına düşen gözlemin, yine aynı kümede yer alan gözlemlerden ortalama uzaklığı esas alınarak bu toplam sapma kareleri en az arttıracak şekilde birleştirilir. Bu teknikte bir eleman bir kümeye bir kez atanır [25].

\subsubsection{K-Ortalamalar Yöntemi}

Özkan [25]'a göre hiyerarşik olmayan kümeleme yöntemleri arasında en yaygın biçimde kullanılan yöntemlerden biri K-Ortalamalar yöntemidir. Yöntem uygulanmadan önce $\mathrm{k}$ küme sayıs1 belirlenir ve bu kümelere mevcut gözlem değerleri isteğe bağlı olarak atanır. K-Ortalamalar yönteminde hem kümeler içi varyans, hem de kümeler arası mesafeler önemlidir ve veriler kendilerine en yakın merkezin ait olduğu kümeye atanana kadar dinamik bir şekilde kümelerden çıkarılırlar veya kümelere eklenirler [25].

Kullanılan yaklaşım ile ilgili oluşturulan iş akışı Şekil 1' de gösterilmektedir.

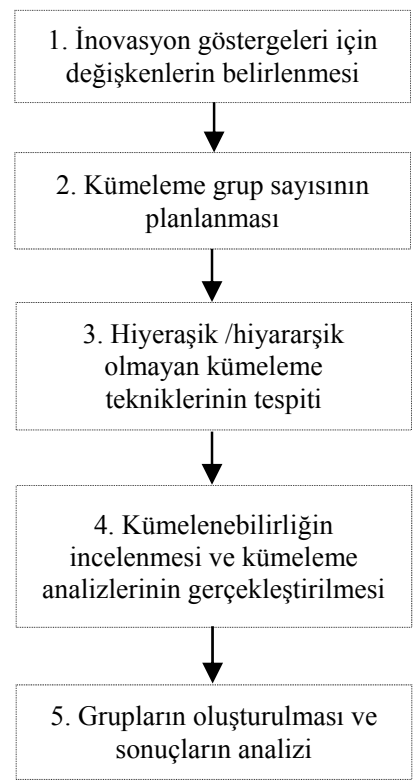

Şekil 1. Kümeleme analizi iş akışı

\section{BULGULAR VE TARTIŞMA}

KİE endeks değerleri kullanılarak yapılan analizdeki sonuçlar 3 ve 5 küme sayısı için 
Çizelge 3'te verilmiştir. Endeks değerlerine bağlı bu kümeler ülkeleri inovasyon seviyeleri bakımından "Düşük-Orta-Yüksek" veya "DüşükOrta Düşük-Orta-Orta Yüksek-Yüksek” şeklinde kümelemekte kullanılabilir. Böyle bir kümeleme yapılacak olduğunda sadece endeks değerlerine bakılarak hangi değerlerden kümelemenin yapılacağına karar vermek zordur. Kümeleme analizi ile bu kümeler analitik bir şekilde belirlenmiştir. $\mathrm{Bu}$ sonuçların KİE değerleri üzerinden daha genel bir sınıflandırma amaçlı da kullanılabilir olması da bu çalışmanın literatüre bir diğer katkısıdır.

Sonuçlar incelendiğinde 3'lü kümeleme için KOrtalamalar tekniği KİE değerlerine göre kümeleri 31,42 ve 53 ülke şeklinde belirlerken Ward's tekniği kümeleri 41, 46 ve 39 ülke şeklinde belirlemiştir. Buna karşılık 5'li kümeleme için iki yöntem de İrlanda, İsrail ve Kore dışında aynı kümeleri vermiştir. K-Ortalamalar yöntemi yüksek kümeye ilk 9 ülkeyi dahil ederken, Ward's tekniği ilk 12 ülkeyi dahil etmiş ve Orta-Düşük kümesinde geriye kalan ilk 26 ülke yer almıştır. Buradan ülkeleri KİE değerlerine göre 5'li gruplara ayırmanın daha uygun olacağı sonucuna varılabilir.

Ülkelerin mevcut durumunu bu şekilde kümelemek mümkün olsa da KİE değerlerinin 0 ile 100 arasında değer aldığı düşünüldüğünde bu kümeleme görece bir kümeleme olarak görülebilmektedir. Bunu yapmak için Çizelge 3'teki değerlerden 5 kümeli durum düşünülmüştür. 2018 verilerinde maksimum değer 68,4 olup sınır değerleri 0-100 aralığına doğrusal bir şekilde yansitıldığında 100-84,80 83,63-73,54 $71,35-59,50 \quad 56,87-42,84$ ve $41,96-21,93$ aralıklarına ulaşılmaktadır. $\mathrm{Bu}$ sınır değerlerine göre KİE değerleri üzerinden aşağıdaki genel kümeleme uygulanabilir görülmektedir.
- Yüksek (85 - 100)

- Orta Yüksek (70 - 85)

- Orta (60 - 70)

- Düşük Orta (40 - 60)

- Düşük (0 - 40)

Bu genel kümeleme çerçevesinde ülkelerin mevcut durumunda Yüksek ve Orta Yüksek kümesine dahil bir ülke görülmemektedir ve Yüksek Orta kümesine tek yakın ülke İsviçre olarak ortaya çıkmaktadır.

Çalışmanın bir sonraki aşamasında 21 değişken kullanılarak kümeleme analizi gerçekleştirilmiş ve elde edilen sonuçlar Çizelge 4'te gösterilmiştir. Burada grup numaraları herhangi bir üstünlük belirlemek şeklinde değil ülkelerin benzerliği şeklinde yorumlanmalıdır.

Çizelge 4'te rakamların '*' işareti ile birlikte gösterildiği hücreler iki yöntemin de aynı kümelemeyi verdiği durumları göstermektedir. Çizelge 4'teki kümeleme analizi sonuçları incelendiğinde ilk göze çarpan nokta, KİE değerlerine göre siralamada 1-13 arasında olan ülkeler ve 97-126 arasında olan ülkelerin kendileri arasında, küme sayısından ve yöntemden bağımsız olarak her zaman birlikte kümelenmesidir. $\mathrm{Bu}$ ülkeler için endeks sıralaması ve kümeleme analizi sonuçları tutarlılık sergilemektedir. $\mathrm{Bu}$ durumda KİE endeksinin tek başına benzerlik ve farklılıkları yansıtmada etkin olduğu sonucuna varılabilir. Benzer şekilde, endekse göre siralamada ilk 30-66 arasında yer alan ülkelere bakıldığında bu ülkelerin de KİE değerlerine paralel bir şekilde ve genellikle her iki yöntem ve farklı küme sayıları için benzer kümelendikleri görülmektedir.

Çizelge 3. KİE değerleri kullanılarak kümeleme analizi

\begin{tabular}{|c|c|c|c|c|c|c|c|c|}
\hline & \multicolumn{4}{|c|}{$k=3$} & \multicolumn{4}{|c|}{$k=5$} \\
\hline Grup & K-Ort. & KİE & Ward's & KİE & K-Ort. & KİE & Ward's & KİE \\
\hline 1 & Ü1-Ü31 & $68,4-46,3$ & Ü1-Ü41 & $68,4-40,7$ & Ü1-Ü9 & $68,4-58,0$ & Ü1-Ü12 & $68,4-56,6$ \\
\hline 2 & Ü32-Ü73 & $45,7-31,6$ & Ü42-Ü87 & $38,9-29,3$ & Ü10-Ü26 & $57,2-50,3$ & Ü13-Ü26 & $54,9-50,3$ \\
\hline 3 & Ü74-Ü126 & $31,4-15,0$ & Ü88-Ü126 & $28,7-15,0$ & Ü27-ய̈41 & $48,8-40,7$ & Ü27-Ü41 & $48,8-40$ \\
\hline 4 & & & & & Ü42-Ü87 & $38,9-29,3$ & Ü42-Ü87 & $38,9-29,3$ \\
\hline 5 & & & & & Ü88-Ü126 & $28,7-15,0$ & Ü88-Ü126 & $28,7-15,0$ \\
\hline
\end{tabular}


Çizelge 4. 21 değişken için kümeleme analizi sonuçları

\begin{tabular}{|c|c|c|c|c|c|c|}
\hline & \multicolumn{2}{|c|}{$\mathrm{k}=3$} & \multicolumn{2}{|c|}{$\mathrm{k}=4$} & \multicolumn{2}{|c|}{$\mathrm{k}=5$} \\
\hline & Ward's & K-Ort & Ward's & K-Ort & Ward's & K-Ort \\
\hline Ü1-İsviçre & $1 *$ & $1 *$ & $1 *$ & $1 *$ & $1 *$ & $1 *$ \\
\hline Ü2-Hollanda & $1 *$ & $1 *$ & $1 *$ & $1 *$ & $1 *$ & $1 *$ \\
\hline Ü3-İsveç & $1 *$ & $1 *$ & $1 *$ & $1 *$ & $1 *$ & $1 *$ \\
\hline Ü4-Birleşik Krallık & $1 *$ & $1 *$ & $1 *$ & $1 *$ & $1 *$ & $1 *$ \\
\hline Ü5-Singapur & $1 *$ & $1 *$ & $1 *$ & $1 *$ & 1 & 4 \\
\hline Ü6-Amerika & $1 *$ & $1 *$ & $1 *$ & $1 *$ & $1 *$ & $1 *$ \\
\hline Ü7-Finlandiya & $1 *$ & $1 *$ & $1 *$ & $1 *$ & $1 *$ & $1 *$ \\
\hline Ü8-Danimarka & $1 *$ & $1 *$ & $1 *$ & $1 *$ & $1 *$ & $1 *$ \\
\hline Ü9-Almanya & $1 *$ & $1 *$ & $1 *$ & $1 *$ & $1 *$ & $1 *$ \\
\hline Ü10-İrlanda & $1 *$ & $1 *$ & $1 *$ & $1 *$ & 1 & 4 \\
\hline Ü11-İsrail & $1 *$ & $1 *$ & $1 *$ & $1 *$ & $1 *$ & $1 *$ \\
\hline Ü12-Kore & $1 *$ & $1 *$ & $1 *$ & $1 *$ & $1 *$ & $1 *$ \\
\hline Ü13-Japonya & $1 *$ & $1 *$ & $1 *$ & $1 *$ & $1 *$ & $1 *$ \\
\hline Ü14-Hong Kong, Çin) & $1 *$ & $1 *$ & 1 & 2 & 1 & 4 \\
\hline Ü15-Lüksemburg & $1 *$ & $1 *$ & 1 & 2 & 1 & 2 \\
\hline Ü16-Fransa & $1 *$ & $1 *$ & $1 *$ & $1 *$ & 1 & 4 \\
\hline Ü17-Çin & $1 *$ & $1 *$ & 1 & 2 & 1 & 2 \\
\hline Ü18-Kanada & $1 *$ & $1 *$ & $1 *$ & $1 *$ & $1 *$ & $1 *$ \\
\hline Ü19-Norveç & $1 *$ & $1 *$ & 1 & 2 & 1 & 4 \\
\hline Ü20-Avustralya & $1 *$ & $1 *$ & 1 & 2 & 1 & 4 \\
\hline Ü21-Avusturya & $1 *$ & $1 *$ & 1 & 2 & 1 & 4 \\
\hline Ü22-Yeni Zelanda & $1 *$ & $1 *$ & 1 & 2 & 1 & 4 \\
\hline Ü23-İzlanda & $1 *$ & $1 *$ & 1 & 2 & 1 & 4 \\
\hline Ü24-Estonya & 2 & 1 & $2 *$ & $2 *$ & $2 *$ & $2 *$ \\
\hline Ü25-Belçika & $1 *$ & $1 *$ & 1 & 2 & 1 & 4 \\
\hline Ü26-Malta & $2 *$ & $2 *$ & $2 *$ & $2 *$ & $2 *$ & $2 *$ \\
\hline Ü27-Çek Cumhuriyeti & $2 *$ & $2 *$ & $2 *$ & $2 *$ & $2 *$ & $2 *$ \\
\hline Ü28-İspanya & 2 & 1 & $2 *$ & $2 *$ & $2 *$ & $2 *$ \\
\hline Ü29-K1bris & 1 & 2 & 1 & 2 & 1 & 2 \\
\hline Ü30-Slovenya & $2 *$ & $2 *$ & $2 *$ & $2 *$ & $2 *$ & $2 *$ \\
\hline Ü31-İtalya & $2 *$ & $2 *$ & $2 *$ & 2* & $2 *$ & $2 *$ \\
\hline Ü32-Portekiz & $2 *$ & $2 *$ & $2 *$ & $2 *$ & $2 *$ & $2 *$ \\
\hline Ü33-Macaristan & $2 *$ & $2 *$ & $2 *$ & $2 *$ & $2 *$ & $2 *$ \\
\hline Ü34-Letonya & $2 *$ & $2 *$ & $2 *$ & $2 *$ & $2 *$ & $2 *$ \\
\hline Ü35-Malezya & $2 *$ & $2 *$ & $2 *$ & $2 *$ & $2 *$ & $2 *$ \\
\hline Ü36-Slovakya & $2 *$ & $2 *$ & $2 *$ & $2 *$ & $2 *$ & $2 *$ \\
\hline Ü37-Bulgaristan & $2 *$ & $2 *$ & 2 & 3 & $2 *$ & $2 *$ \\
\hline Ü38-Birleşik Arap Emir. & $2 *$ & $2 *$ & $2 *$ & $2 *$ & $2 *$ & $2 *$ \\
\hline Ü39-Polonya & $2 *$ & $2 *$ & $2 *$ & $2 *$ & $2 *$ & $2 *$ \\
\hline Ü40-Litvanya & $2 *$ & $2 *$ & $2 *$ & $2 *$ & $2 *$ & $2 *$ \\
\hline Ü41-Hırvatistan & $2 *$ & $2 *$ & 2 & 3 & $2 *$ & $2 *$ \\
\hline Ü42-Yunanistan & $2 *$ & $2 *$ & $3 *$ & 3* & $3 *$ & $3 *$ \\
\hline Ü43-Ukrayna & $2 *$ & $2 *$ & $3 *$ & 3* & $3 *$ & $3 *$ \\
\hline Ü44-Tayland & $2 *$ & $2 *$ & $3 *$ & $3 *$ & $3 *$ & $3 *$ \\
\hline
\end{tabular}




\begin{tabular}{|c|c|c|c|c|c|c|}
\hline Ü45-Vietnam & $2 *$ & $2 *$ & 3* & $3 *$ & $3 *$ & $3 *$ \\
\hline Ü46-Rusya & $2 *$ & $2 *$ & $3 *$ & $3 *$ & $3 *$ & $3 *$ \\
\hline Ü47-Şili & $2 *$ & $2 *$ & 3* & 3* & $3 *$ & $3 *$ \\
\hline Ü48-Romanya & $2 *$ & $2 *$ & 3* & 3* & $3 *$ & $3 *$ \\
\hline Ü49-Türkiye & $2 *$ & $2 *$ & $3 *$ & $3 *$ & $3 *$ & $3 *$ \\
\hline Ü50-Moldova & $2 *$ & $2 *$ & 3* & 3* & 4 & 3 \\
\hline Ü51-Katar & $2 *$ & $2 *$ & 3* & 3* & $3 *$ & $3 *$ \\
\hline Ü52-Karadağ & $2 *$ & $2 *$ & $3 *$ & $3 *$ & 4 & 3 \\
\hline Ü53-Moğolistan & $2 *$ & $2 *$ & $3 *$ & 3* & 4 & 3 \\
\hline Ü54-Kosta Rika & $2 *$ & $2 *$ & $3 *$ & $3 *$ & 3* & $3 *$ \\
\hline Ü55-Sırbistan & $2 *$ & $2 *$ & $3 *$ & $3 *$ & $3 *$ & $3 *$ \\
\hline Ü56-Meksika & $2 *$ & $2 *$ & 3* & 3* & 3* & $3 *$ \\
\hline Ü57-Hindistan & $2 *$ & $2 *$ & 3* & 3* & 3* & $3 *$ \\
\hline Ü58-Güney Afrika & $2 *$ & $2 *$ & $3 *$ & 3* & 4 & 3 \\
\hline Ü59-Gürcistan & $2 *$ & $2 *$ & 3* & 3* & 4 & 3 \\
\hline Ü60-Kuveyt & $2 *$ & $2 *$ & $3 *$ & $3 *$ & $3 *$ & $3 *$ \\
\hline Ü61- Suudi Arabistan & $2 *$ & $2 *$ & $3 *$ & $3 *$ & $3 *$ & $3 *$ \\
\hline Ü62-Uruguay & $2 *$ & $2 *$ & $3 *$ & 3* & $3 *$ & $3 *$ \\
\hline Ü63-Kolombiya & $2 *$ & $2 *$ & $3 *$ & $3 *$ & $3 *$ & $3 *$ \\
\hline Ü64-Brezilya & $2 *$ & $2 *$ & 3* & 3* & $3 *$ & $3 *$ \\
\hline Ü65-İran İslam Cumh. & 2 & 3 & 3* & 3* & $3 *$ & $3 *$ \\
\hline Ü66-Tunus & $2 *$ & $2 *$ & 3* & $3 *$ & $3 *$ & $3 *$ \\
\hline Ü67-Brunei Sultanlığ1 & $2 *$ & $2 *$ & $3 *$ & $3 *$ & 4 & 3 \\
\hline Ü68-Ermenistan & 2 & 3 & 3* & 3* & 4 & 3 \\
\hline Ü69-Umman & $2 *$ & $2 *$ & $3 *$ & 3* & $3 *$ & $3 *$ \\
\hline Ü70-Panama & 2 & 3 & $3 *$ & $3 *$ & 4 & 3 \\
\hline Ü71-Peru & 2 & 3 & 3* & $3 *$ & $3 *$ & $3 *$ \\
\hline Ü72-Bahreyn & $2 *$ & $2 *$ & $3 *$ & 3* & $3 *$ & $3 *$ \\
\hline Ü73-Filipinler & 2 & 3 & $3 *$ & $3 *$ & $3 *$ & $3 *$ \\
\hline Ü74-Kazakistan & $2 *$ & $2 *$ & $3 *$ & 3* & 4 & 3 \\
\hline Ü75-Mauritius & $2 *$ & $2 *$ & 3* & 3* & $3 *$ & $3 *$ \\
\hline Ü76-Fas & 2 & 3 & $3 *$ & 3* & $3 *$ & $3 *$ \\
\hline Ü77-Bosna Hersek & 2 & 2 & 3* & 3* & 4 & 3 \\
\hline Ü78-Kenya & $3 *$ & $3 *$ & 4* & $4 *$ & $5 *$ & $5 *$ \\
\hline Ü79-Ürdün & 2 & 3 & $3 *$ & $3 *$ & $3 *$ & $3 *$ \\
\hline Ü80-Arjantin & $2 *$ & $2 *$ & 3* & $3 *$ & $3 *$ & $3 *$ \\
\hline Ü81-Jamaika & 2 & 3 & 3 & 4 & 4 & 3 \\
\hline Ü82-Azerbaycan & 2 & 3 & $3 *$ & $3 *$ & 4 & 3 \\
\hline Ü83-Arnavutluk & 2 & 3 & 3* & $3 *$ & 4 & 3 \\
\hline Ü84-Yugoslavya & $2 *$ & $2 *$ & $3 *$ & $3 *$ & 4 & 3 \\
\hline Ü85-Endonezya & $3 *$ & $3 *$ & 4* & 4* & $5 *$ & $5 *$ \\
\hline Ü86-Belarus & $2 *$ & $2 *$ & $3 *$ & $3 *$ & 4 & 3 \\
\hline Ü87-Dominik Cumh. & $3 *$ & $3 *$ & $4 *$ & 4* & 5 & 3 \\
\hline Ü88-Sri Lanka & $3 *$ & $3 *$ & $4 *$ & $4 *$ & $5 *$ & $5 *$ \\
\hline Ü89-Paraguay & $3 *$ & 3* & 4* & 4* & $5 *$ & $5 *$ \\
\hline Ü90-Lübnan & 2 & 3 & $3 *$ & $3 *$ & 4 & 3 \\
\hline Ü91-Botsvana & 2 & 3 & 3 & 4 & 4 & 3 \\
\hline
\end{tabular}




\begin{tabular}{|c|c|c|c|c|c|c|}
\hline Ü92-Tanzanya & $3 *$ & $3 *$ & $4 *$ & $4 *$ & $5^{*}$ & $5 *$ \\
\hline Ü93-Namibya & 2 & 3 & 3 & 4 & 4 & 3 \\
\hline Ü94-Kırg1zistan & 2 & 3 & 3 & 4 & 4 & 5 \\
\hline Ü95-Misır & $3 *$ & $3 *$ & $4 *$ & $4 *$ & 5* & $5 *$ \\
\hline Ü96-Trinidad ve Tobago & 2 & 3 & 3 & 4 & 4 & 5 \\
\hline Ü97-Ekvador & 3* & 3* & 4* & 4* & $5 *$ & $5 *$ \\
\hline Ü98-Kamboçya & 3* & 3* & 4* & 4* & $5^{*}$ & $5 *$ \\
\hline Ü99-Ruanda & $3 *$ & $3 *$ & 4* & 4* & $5 *$ & $5 *$ \\
\hline Ü100Senegal & $3 *$ & $3 *$ & $4 *$ & $4 *$ & $5 *$ & $5 *$ \\
\hline Ü101-Tacikistan & $3 *$ & $3 *$ & 4* & 4* & $5^{*}$ & $5 *$ \\
\hline Ü102-Guatemala & $3 *$ & $3 *$ & $4 *$ & 4* & $5 *$ & $5 *$ \\
\hline Ü103-Uganda & $3 *$ & $3 *$ & 4* & 4* & $5 *$ & $5 *$ \\
\hline Ü104-El Salvador & $3 *$ & 3* & 4* & 4* & $5 *$ & $5 *$ \\
\hline Ü105-Honduras & $3 *$ & $3 *$ & 4* & 4* & $5 *$ & $5 *$ \\
\hline Ü106-Madagaskar & 3* & 3* & 4* & 4* & $5 *$ & $5 *$ \\
\hline Ü107-Gana & $3 *$ & $3 *$ & 4* & 4* & $5 *$ & $5 *$ \\
\hline Ü108-Nepal & $3 *$ & $3 *$ & 4* & 4* & $5 *$ & $5 *$ \\
\hline Ü109-Pakistan & $3 *$ & $3 *$ & 4* & 4* & $5 *$ & $5 *$ \\
\hline Ü110-Cezayir & $3 *$ & $3 *$ & $4 *$ & 4* & $5 *$ & $5 *$ \\
\hline Ü111-Kamerun & $3 *$ & $3 *$ & $4 *$ & 4* & $5 *$ & $5 *$ \\
\hline Ü112-Mali & $3 *$ & $3 *$ & 4* & $4 *$ & $5 *$ & $5 *$ \\
\hline Ü113-Zimbabwe & 3* & 3* & 4* & 4* & $5 *$ & $5 *$ \\
\hline Ü114-Malawi & $3 *$ & $3 *$ & $4 *$ & 4* & $5 *$ & $5 *$ \\
\hline Ü115-Mozambik & 3* & 3* & 4* & 4* & $5 *$ & $5 *$ \\
\hline Ü116-Bangladeş & 3* & 3* & 4* & 4* & $5 *$ & $5 *$ \\
\hline Ü117-Bolivya & $3 *$ & 3* & 4* & 4* & $5 *$ & $5 *$ \\
\hline Ü118-Nijerya & $3 *$ & 3* & 4* & 4* & $5 *$ & $5 *$ \\
\hline Ü119-Gine & $3 *$ & $3 *$ & 4* & 4* & $5 *$ & $5 *$ \\
\hline Ü120-Zambiya & $3 *$ & $3 *$ & $4 *$ & $4 *$ & $5 *$ & $5 *$ \\
\hline Ü121-Benin & $3 *$ & $3 *$ & $4 *$ & 4* & $5 *$ & $5 *$ \\
\hline Ü122- Nijer & 3* & $3 *$ & 4* & 4* & $5 *$ & $5 *$ \\
\hline Ü123-Fildişi Sahili & $3 *$ & $3 *$ & $4 *$ & 4* & $5 *$ & $5 *$ \\
\hline Ü124-Burkina Faso & 3* & 3* & $4 *$ & 4* & $5 *$ & $5 *$ \\
\hline Ü125-Togo & 3* & 3* & $4 *$ & 4* & $5 *$ & $5 *$ \\
\hline Ü126-Yemen & $3 *$ & $3 *$ & $4 *$ & $4 *$ & $5 *$ & $5 *$ \\
\hline
\end{tabular}

* İki yöntem için aynı kümelemeyi verdiği durumları göstermektedir.

Endekse bağlı sıralamada 67-96 arasında yer alan ülkeler incelendiğinde iki yöntemin farklı sonuçlar verebildiği görülmektedir. Örneğin, bu aralıktaki ülkeler arasından, 5 kümeli durumda KOrtalamalar tekniği kullanıldığında Brunei Sultanlığı, Ermenistan, Panama, Kazakistan, Bosna Hersek, Jamaica, Azerbaycan, Arnavutluk, Yugoslavya ve Belarus arasında Ward's tekniğinde görülmeyen benzerlik ortaya çıkarmıştır. Bundan dolayı farklı bir kümede yer almaları gerekmektedir. Endeks siralamasında 84, 86 ve 90. olan, sirasiyla, Yugoslavya, Belarus ve Lübnan'ın sıralamadaki 30-64 aralığındaki ülkelere benzerlik gösterip genelde aynı kümelere atanırken, sıralamada 78. sırada, daha yukarıda, yer alan Kenya siralamada 97'den sonraki ülkelerle kümelenmiştir. $\mathrm{Bu}$ durum, analiz sonuçları ile KİE değerlerinin paralel olmayıp, bazı durumlarda endekse yansıyamamış benzerliklerin kümeleme analizi ile ortaya konulabileceğini göstermektedir. 
Ward's tekniği sonuçlarına göre endeks sıralamasındaki ilk 23 ülke her zaman aynı kümeye atanırken, K-Ortalamalar yöntemi sonuçlarına göre, 4 ve 5 küme sayıları için, endeks sıralamasında 14-23 aralığındaki ülkeler, Kanada ve Fransa hariç, sıralamadaki ilk 13'ten ayrı kümeye atanmıştır. Kanada tüm yöntemlerde ve tüm küme sayıları için ilk 13'teki ülkelerle aynı kümeye atanırken, Fransa K-Ortalamaların 5'li küme sonucu hariç ilk 13'teki ülkelerle aynı kümeye atanmıştır. $\mathrm{Bu}$ durum, bu ülkeler için kümeleme analizinin endeks değerine yansıyamamış benzerlikler ortaya koyabildiği şeklinde yorumlanabilir. Buna benzer ilginç bir durum endeks siralamasinda 25 ve 29 . olan Belçika ve Kıbrıs için de söz konusudur. Ward's tekniği her iki ülkeyi ilk 13'teki ülkelerle aynı kümeye atarken, K-Ortalamalar bu iki ülkeyi ilk 13 'teki ülkelerden farklı bir kümeye atamıştır. Bu bağlamda KİE değerleri ile K-Ortalamalar benzer davranırken, Ward's tekniği farklı sonuçlar vermektedir.

KİE değerlerinin 21 değişken üzerinden incelenmesine ek olarak, kümeleme analizi kümelerin oluşturulmasında hangi faktörlerin etkili olduğunu da ortaya koyabilmektedir. Bu bilgi ANOVA (Tek Yönlü Varyans Analizi) ile elde edilebilmektedir. En fazla ortalama hata karesine sahip değişken, kümelerin ayrılmasında en az etkisi olan değişken anlamına gelmektedir. Bu çalışmada sadece K-Ortalamalar yöntemine ait ve küme sayısı 3 için ANOVA sonuçları Çizelge 5'te gösterilmektedir. Çizelge 5'te tüm değişkenler 0,05 'ten küçük anlam düzeyine sahip olduğu için anlamlıdır. En fazla ortalama hata karesine ve en düşük $\mathrm{F}$ değerlerinden birine sahip olan X10 (Kredi) değişkeninin, kümelemede en az etkiye sahip olduğu görülmektedir. Ortalama hata kareleri çok düşük olmasa da en yüksek $F$ değerine sahip X6 (Bilgi ve İletişim Teknolojileri) ve X7 (ArGe) değişkenlerinin kümelemede en fazla etkiye sahip oldukları görülmektedir. Buradan ülkelerin inovasyon seyirlerini iyileştirmeleri için en çok Bilgi ve İletişim Teknolojileri ile ArGe alanında ilerleme kaydetmeleri gerektiği sonucu çıkarılabilir.

\section{SONUÇ}

Çalışmada KİE 2018 Raporundaki veriler kullanılarak kümeleme analizi yapılmıștır. Bu bağlamda ülkelerin birbirlerine benzerlikleri dikkate alınarak endeks değerleri ile bu benzerliklerin uyumu incelenmiştir. $\mathrm{Bu}$ aynı zamanda KİE endeksinin benzerlikleri ve farklılıkları ne kadar etkin biçimde yansıttığını anlamak amacıyla kullanılmıştır ve endeksin bunu etkin bir şekilde yapabildiği gözlenmiştir. Benzer bir analiz geliştirilmiş herhangi bir endeks için de ileriki çalışmalarda kullanılabilir. Kümeleme analizi KİE değerleri üzerinden kümeleme ve 21 değişken üzerinden kümeleme olmak üzere iki amaçla kullanılmıştır.

Birinci amaç ülkelerin KİE değerleri dikkate alınarak 3 ve 5 kümeye ayrılmasıdır. Sadece KİE değerleri üzerinden bir sıralama yapmak mümkün olsa da kümelerin nasıl belirleneceği konusu belirsizdir ve kümeleme analizi ülkelerin bu endeks üzerinden Düşük - Orta - Yüksek veya Düşük - Düşük Orta - Orta - Orta Yüksek - Yüksek şeklinde kümelemesini mümkün kılmıştır. Yapılan araştırmalarda bu tür bir analiz kullanılarak böyle bir kümeleme yapan bir çalışmaya rastlanmamıştır. $\mathrm{Bu}$ kümeleme ülkelerin mevcut durumları için görece şeklinde yapıldığı için yeterli olmayabileceğinden genel bir kümeleme yapmak da önem arz etmektedir. $\mathrm{Bu}$ da yine ülkelerin mevcut durumlarının kümeleme analizi sonuçlarının KİE'nin alabileceği tüm değerlere yansıtılması şeklinde gerçekleştirilmiştir. $\mathrm{Bu}$ yöntem farklı ölçümler için geliştirilmiş başka herhangi bir endeks ile ilgili kümeler yaratmak amaciyla da kullanılabilecektir. Analizin ikinci amacı ise endeks oluşturulurken kullanılan 21 değişken kullanılarak inovasyon anlamında birbirlerine benzerlik gösteren ülkelerin belirlenmesidir. $\mathrm{Bu}$ amaç 3, 4 ve 5 gibi değişik küme sayıları kullanılarak ve Ward's tekniği ve KOrtalamalar yöntemi gibi iki farklı yöntem kullanılarak gerçekleştirilmiştir. Kümeleme analizi sonuçları ile KİE değerlerine göre sıralamanın birbirleriyle tutarlılık gösterdiği durumlar olsa da farklı davrandıkları noktalar da gözlenmiştir. 
Çizelge 5. 3 Kümeli K-ortalamalar için ANOVA çizelgesi

\begin{tabular}{|c|c|c|c|c|c|c|}
\hline & \multicolumn{2}{|c|}{ Küme } & \multicolumn{2}{c|}{ Hata } & \multirow{2}{*}{ F } & \multirow{2}{*}{ Önem } \\
\cline { 2 - 5 } & Ort. Kare & sd & Ort. Kare & sd & & \\
\hline X1 & 17064,58 & 2 & 145,877 & 123 & 116,979 & 0 \\
\hline X2 & 10101,1 & 2 & 136,461 & 123 & 74,022 & 0 \\
\hline X3 & 4853,295 & 2 & 68,253 & 123 & 71,107 & 0 \\
\hline X4 & 5821,46 & 2 & 130,336 & 123 & 44,665 & 0 \\
\hline X5 & 8218,386 & 2 & 181,449 & 123 & 45,293 & 0 \\
\hline X6 & 30721,97 & 2 & 120,792 & 123 & 254,339 & 0 \\
\hline X7 & 21225,58 & 2 & 111,842 & 123 & 189,783 & 0 \\
\hline X8 & 3814,178 & 2 & 108,262 & 123 & 35,231 & 0 \\
\hline X9 & 2734,807 & 2 & 109,249 & 123 & 25,033 & 0 \\
\hline X10 & 6291,638 & 2 & 189,207 & 123 & 33,253 & 0 \\
\hline X11 & 2259,042 & 2 & 120,126 & 123 & 18,806 & 0 \\
\hline X12 & 4561,458 & 2 & 100,914 & 123 & 45,201 & 0 \\
\hline X13 & 15465,28 & 2 & 115,053 & 123 & 134,419 & 0 \\
\hline X14 & 4101,498 & 2 & 112,772 & 123 & 36,37 & 0 \\
\hline X15 & 4479,036 & 2 & 77,894 & 123 & 57,502 & 0 \\
\hline X16 & 16251,64 & 2 & 126,819 & 123 & 128,148 & 0 \\
\hline X17 & 5222,595 & 2 & 124,86 & 123 & 41,827 & 0 \\
\hline X18 & 6733,945 & 2 & 137,205 & 123 & 49,079 & 0 \\
\hline X19 & 5089,373 & 2 & 115,146 & 123 & 44,199 & 0 \\
\hline X20 & 6454,463 & 2 & 117,495 & 123 & 54,934 & 0 \\
\hline X21 & 13822,8 & 2 & 113,883 & 123 & 121,377 & 0 \\
\hline
\end{tabular}

Yüksek ve düşük KİE değerlerine sahip ülkeler için benzerlikler ve endeks sıralaması paralellik arz etmiş olsa da endeks sıralamasında ara değerlerde yer alan ülkeler için endekse paralel olmayacak şekilde benzerliklerin ortaya çıkarıldığı gözlenmiştir. Örneğin, Kanada endeks sıralamasında 18. sırada yer almasına rağmen kümeleme analizindeki her iki yöntem ve 3, 4 ve 5 küme sayıları için endeks sıralamasındaki ilk 13 ülke ile beraber kümelenmiştir.

Kümeleme analizi, verilerin tümü üzerinden bir değerlendirme yapması dolayısıyla, tek bir sayısal değer ifade eden endekslerin ortaya koyamayacağ bazı benzerlikleri ortaya koyma şansına sahiptir. $\mathrm{Bu}$ tür bir analiz, endekslere dayalı sıralamalarda hem endeksin veriyi yansitma gücünü ortaya koymak, hem de kümeleme yapmak amaçlı kullanılabilecektir. Benzer şekilde kümeleme analizi ANOVA gibi değerlendirmelerle kümelerin oluşturulmasında etkili olan değişkenlerin belirlenmesine olanak sağlar. Gelecek çalışmalarda farklı küme sayıları ve farklı yöntemler için bu tür sonuçlar karşılaştırmalı olarak değerlendirilebilir. Yöntem veya küme sayısı seçimi ile ilgili bir çalışma yapılarak benzer analiz yöntemi başka endekslerde kullanılabilir.

\section{KAYNAKLAR}

1. Brocker, J., Dohse, D., Soltwedel, R., 2012. Innovation Clusters and Interregional Competition. Springer, Berlin.

2. Saraceni, A.V., Martind de Resende, L.M., Serpe, L.F., Junior, PPA., 2015. A Comparative Analysis Between Clustered and Non-Clustered Companies Using Innovation Indicators. IFAC-PapersOnLine, 48(3), 155-160.

3. Lee, J., Kim, C., Choi, G., 2018. Exploring Data Envelopment Analysis for Measuring Collaborated Innovation Efficiency of Small and Medium-Sized Enterprises in Korea. 
European Journal of Operational Research, https://doi.org/10.1016/j.ejor.2018.08.044.

4. Xie, X., Huo, J., Zou, H., 2019. Green Process Innovation, Green Product Innovation, and Corporate Financial Performance: A Content Analysis Method. Journal of Business Research, https://doi.org/10.1016/j.jbusres.2019.01.010.

5. Baregheh, A., Rowley, J., Sambrook, S. and Davies, D,. 2012. Innovation In Food Sector SMEs. Journal of Small Business and Enterprise Development, 19(2), 300-321, https://doi.org/10.1108/14626001211223919.

6. Rani, K.M., 2013. Innovation In Indian Women Micro-Enterprises. IPE Journal of Management, 3(2), 76-94.

7. Yıldı, T., Aykanat, T., 2015. Clustering and Innovation Concepts and Innovative Clusters: An Application on Technoparks in Turkey. Procedia, 195, 1196-1205.

8. Franco, C., Oliveira, R.H., 2017. Inputs and Outputs of Innovation: Analysis of the BRICS: Theme 6-Innovation Technology and Competitiveness. RAI Revista de Administração e Inovação, 14(1), 79-89.

9. Dziallas, M., Blind, K., 2018. Innovation Indicators Throughout The Innovation Process: An Extensive Literature Analysis. Technovation, $\quad$ https://doi.org/10.1016/j. technovation.2018.05.005.

10. Silva, C.M., Gavião, L.O., Gomez, C.F.S., Lima, G.B.A., 2017. A Proposal for the Application of Multicriteria Analysis to Rank Countries According to Innovation Using the Indicators Provided by the World Intellectual Property Organization. RAI Revista de Administração e Inovação, 14(3), 188-198.

11. Adolfsson, A., Ackermana, M., Brownsteinb, N.C., 2019. To Cluster, or Not to Cluster: An Analysis of Clusterability Methods, Pattern Recognition. 88, 13-26.

12. Çakmak, Z., Uzgören, N., Keçek G., 2005. Kümeleme Analizi Teknikleri ile İllerin Kültürel Yapılarına Göre Sınıflandırılması ve Değişimlerinin İncelenmesi. Dumlupınar Üniversitesi Sosyal Bilimler Dergisi, 12, 187-205.

13. Şekerler, A., 2008. Trafik Kaza Verilerinin Kümeleme Analizi Yöntemi ile İncelenmesi.
Yüksek Lisans Tezi, Pamukkale Üniversitesi, Fen Bilimleri Enstitüsü, İnşaat Mühendisliği Bölümü, İnşaat Mühendisliği Anabilim Dalı, 131s, Denizli.

14. Atalay, A., Tortum, A., 2010. Türkiye'deki İllerin 1997-2006 Yılları Arası Trafik Kazalarına Göre Kümeleme Analizi. Pamukkale Üniversitesi Mühendislik Bilimleri Dergisi, 16(3), 335-343.

15. Altun Ada, A., 2011. Kümeleme Analizi ile AB Ülkeleri ve Türkiye'nin Sürdürülebilir Kalkınma Açısından Değerlendirilmesi. Dumlupınar Üniversitesi Sosyal Bilimler Dergisi, 29, 319-332.

16. Rai, A., Tang, X., Brown, P., Keil, M., 2006. Assimilation Patterns in the Use of Electronic Procurement Innovations: A Cluster Analysis. Information and Management, 43, 336-349.

17. Özbek, H., Atik, H., 2013. İnovasyon Göstergeleri Bakımından Türkiye'nin Avrupa Birliği Ülkeleri Arasındaki Yeri: İstatistiksel Bir Analiz. Erciyes Üniversitesi İktisadi ve İdari Bilimler Fakültesi Dergisi, 42, 193-210.

18. Şimşit, Z.T., Fırat, S.Ü.O., Es, H.A., Erdem, M., Topgül, M., Günay, N.S., 2014. Bilgi ve İletişim Teknolojileri Çerçevesinden Küresel İnovasyon Endeksinin Analizi ve Veri Madenciliği Kullanılarak Ülkelerin Kümelenmesi. 1. Yönetim Bilişim Sistemleri Kongresi, İstanbul.

19. Atal, S., 2015. Bulanık Kümeleme Analizi ve OECD Ülkelerinin Gelişmişlik Bakımından Kümelendirilmesi. Yüksek Lisans Tezi, Eskişehir Osmangazi Üniversitesi, Fen Bilimleri Enstitüsü, İstatistik Anabilim Dall, $88 \mathrm{~s}$, Eskişehir.

20. Goncalves, T., Gaio, C., Silva, M., 2018. Target Costing and Innovation-Exploratory Configurations: A Comparison of fsQCA, Multivariate Regression, and Variable Cluster Analysis. Journal of Business Research, 89, 378-384.

21. Proksch, D., Busch-Casler, J., Haberstroh, M. M., Pinkwart, A., 2019. National Health Innovation Systems: Clustering the OECD Countries By Innovative Output in Healthcare Using a Multi Indicator Approach. Research Policy, 48, 169-179. 
22. Engin, M., 2018. Hiyerarşik Kümeleme Analizi ile OECD Ülkelerinin Bilgi Ekonomi İndekslerine Göre Sinıflandırılması. Paradoks Ekonomi Sosyoloji ve Politika Dergisi, 14(1), 73-86.

23. Irac, D., Lopez, J., 2015. Euro Area Structural Convergence? A Multi-Criterion Cluster Analysis. International Economics, 143, 1-22.

24. Lanvin, B., Dutta, S., Wunsch, S., 2018. The Global Innovation Index 2018. www.wipo.int/edocs/pubdocs/en/wipo_pub_gii 2018.pdf (erişim tarihi 22.10.2018).

25. Özkan, Y., 2008. Veri Madenciliği Yöntemleri. Papatya Bilim Yayıncılık, İstanbul. 
